\title{
Constant Boost Control with Third Harmonic Injection for Quasi-Z Source Inverter used in PV Grid-connected System
}

\author{
Zhengyu Zhao, Mohammed A. Elgendy, Matthew Armstrong, Musbahu Muhammad \\ School of Engineering, Newcastle University, Newcastle upon and Tyne, United Kingdom \\ E-Mail: z.zhao6@ncl.ac.uk; mohammed.elgendy@ncl.ac.uk; matthew.armstrong@ncl.ac.uk; \\ Musbahu.Muhammad@ncl.ac.uk
}

\section{Keywords}

«quasi-Z source inverter», «Constant boost control with third harmonic injection», «Maximum power point tracking (MPPT)», «Photovoltaic (PV) grid-connected systems»

\begin{abstract}
Compared to the dual-stage inverter, quasi-Z-source inverter (qZSI) offers higher reliability and lower switch count but suffers from higher voltage stress on components. The qZSI is normally controlled by the simple boost control (SBC) method that adds reference signals to the sinusoidal PWM to generate the shoot-through state. This paper develops a constant boost control method with third harmonic injection. Compared to the SBC, the proposed control method increases the voltage boost and reduces the voltage stress on switches and passive components of the qZSI, making it suitable for PV gridconnected applications. The third harmonic signal is produced and injected in a way that keeps it in phase with the reference sinusoidal signals, regardless of the solar irradiance level. This reduces the total harmonic distortions (THD) and improves the output power quality. Simulation results are presented for validation of the theoretical analysis and controller design.
\end{abstract}

\section{Introduction}

Compared to the classic voltage source inverter (VSI), the Z-source inverter (ZSI) has drawn researchers' interest because of its unique merits. Firstly, a ZSI realized the single-stage buck-boost inversion without employing auxiliary front-end dc-dc converter. Secondly, the ZSI utilizes the shootthrough between upper and lower switches of inverter bridges, eliminating the distortion in the grid current arisen from the use of a deadtime. The ZSI has also better immunity against EMI noise compared to the standard VSI [1]. However, the main drawbacks of the ZSI are high voltage stress across switches and passive components, limited boost ability and discontinuous input current [2]. The quasi-Z source inverter (qZSI) was proposed to overcome the drawbacks of ZSI. The qZSI has a common ground between voltage source and inverter, continuous input current and fewer power devices $[3,4]$. However, its boost capability is the same as that of ZSI, which restricts the scope of its applications. To obtain better boost ability and lower voltage stress on components, many topologies based on qZSI have been proposed in the literature. These include switched-inductor qZSI [5, 6], three-winding switched-coupled inductor qZSI [7] and transformer-based qZSI [8,9].

In addition, to achieve low voltage stress on components, a wide range of the operation area and less commutation per switching cycle, several sinusoidal pulse width modulation (SPWM) techniques for qZSI have been proposed in $[1,10,11]$. Besides the basic simple boost control (SBC) first proposed in [1], three other modified SPWM techniques have been proposed, which are the maximum boost control (MBC) [10], the maximum constant boost control (MCBC) and the constant boost control with third harmonic injection [11]. The simple boost control adds reference signals to the traditional SPWM, which create an extra shoot-through state for voltage step-up. However, the maximum shootthrough duty ratio $\mathrm{D}_{0}$ is limited by modulation index $\mathrm{M}\left(\mathrm{D}_{0} \leq 1-\mathrm{M}\right)$, which restricts the boost capability of the qZSI when using SBC. Furthermore, for high voltage gain applications, the modulation index is decreased with increasing duty ratio, which leads to low output power quality and high components stress. The MBC utilizes all zero states of traditional carrier-based PWM method to 
maximize the shoot-through states, which improves the boost factor and reduces the stresses of components. However, low-frequency ripple components in the inductor current and capacitor voltage cannot be avoided due to the variable shoot-through duty ratio, which requires the increased volume and cost of passive components. Compared to the SBC, the MCBC offers higher boost factor and lower voltage stress on components, while keeping a nearly constant shoot-through duty ratio. Constant boost control with third harmonic injection is also mentioned in [11], in which a thirdharmonic component with $1 / 6$ of fundamental component magnitude is injected to three-phase reference signals. This modified SPWM technique extends the range of the modulation index from 1 to $2 / \sqrt{3}$, which retaining all of the advantages of MCBC. Table I lists the comparison of the above SPWM techniques.

Table I: Comparison of modified SPWM techniques for qZSI.

\begin{tabular}{|l|c|c|c|c|}
\hline Parameters & Simple Boost & Maximum Boost & $\begin{array}{c}\text { Maximum } \\
\text { Constant Boost }\end{array}$ & $\begin{array}{c}\text { Maximum Constant } \\
\text { Boost with Third } \\
\text { Harmonic Injection }\end{array}$ \\
\hline $\begin{array}{l}\text { Shoot-through } \\
\text { Duty Ratio (D })\end{array}$ & $1-\mathrm{M}$ & $\frac{2 \pi-3 \sqrt{3} \mathrm{M}}{2 \pi}$ & $1-\frac{\sqrt{3}}{2} \mathrm{M}$ & $1-\frac{\sqrt{3}}{2} \mathrm{M}$ \\
\hline Boost Factor (B) & $\frac{1}{2 \mathrm{M}-1}$ & $\frac{\pi}{3 \sqrt{3} \mathrm{M}-\pi}$ & $\frac{1}{\sqrt{3} \mathrm{M}-1}$ & $\frac{1}{\sqrt{3} \mathrm{M}-1}$ \\
\hline Voltage Gain (G) & $\frac{\mathrm{M}}{2 \mathrm{M}-1}$ & $\frac{\pi \mathrm{M}}{3 \sqrt{3} \mathrm{M}-\pi}$ & $\frac{\mathrm{M}}{\sqrt{3} \mathrm{M}-1}$ & $\frac{\mathrm{M}}{\sqrt{3} \mathrm{M}-1}$ \\
\hline $\begin{array}{l}\text { Voltage Stress on } \\
\text { Inverter switches }\end{array}$ & $(2 \mathrm{G}-1) \mathrm{V}_{\mathrm{IN}}$ & $\frac{3 \sqrt{3} \mathrm{G}-\pi}{\pi} \mathrm{V}_{\mathrm{IN}}$ & $(\sqrt{3} \mathrm{G}-1) \mathrm{V}_{\mathrm{IN}}$ & $(\sqrt{3} \mathrm{G}-1) \mathrm{V}_{\mathrm{IN}}$ \\
\hline $\begin{array}{l}\text { Maximum } \\
\text { Modulation Index } \\
\text { (M }\end{array}$ & 1 & 1 & 1 & $2 / \sqrt{3}$ \\
\hline
\end{tabular}

This paper proposes a new constant boost control with third harmonic injection strategy for closed loop control of the qZSI in PV grid-connected systems. The proposed control strategy achieves lower voltage stress on passive components and inverter switches and higher voltage gain compared to SBC. Moreover, the proposed control method realizes unity power factor and maximum power delivery to the grid under different irradiance levels. The feasibility of the proposed control method is validated by simulation results using Matlab/ Simulink.

\section{Quasi-Z source inverter}

A typical PV grid-connected system with Quasi-Z source topology is illustrated in Fig. 1. As shown, the PV array is connected to the three-phase inverter via Quasi-Z-source network to realize voltage step-up and maximum power point tracking of the PV array. The voltage and frequency of the inverter are defined by the AC grid. Therefore, only the AC current is required to be regulated in accordance with the generated PV power. A two-stage control strategy for such a PV grid-connected system, including the DC side and AC side control, is proposed in [12]. For the DC-side control, a maximum power point tracking (MPPT) technique is employed to control the shoot-through duty ratio. For ACside control, the capacitor voltage is maintained to a constant value, and the output current is regulated. A similar control strategy is proposed in [13], which applies an MPPT technique to obtain maximum power for DC-side and PQ control to regulate capacitor voltage and output current. The SPWM technique used with the above-mentioned control methods is the basic SBC. 




Fig. 1: The schematic diagram of a typical PV grid-connected system with Quasi-Z source topology

The operating principle of QZSI has been discussed in previous publications [1,10,11]. Shoot-through states are introduced in traditional sinusoidal PWM (SPWM) to realize the step-up function. The capacitor voltage $\left(\mathrm{V}_{\mathrm{C} 1}\right)$ and $\left(\mathrm{V}_{\mathrm{C} 2}\right)$ can be obtained from shoot-through duty ratio $\mathrm{D}_{0}$ and the input voltage $\left(\mathrm{V}_{\text {in }}\right)$ as follows:

$\mathrm{V}_{\mathrm{C} 1}=\frac{1-\mathrm{D}_{0}}{1-2 \mathrm{D}_{0}} \mathrm{~V}_{\mathrm{in}}$

$\mathrm{V}_{\mathrm{C} 2}=\frac{\mathrm{D}_{0}}{1-2 \mathrm{D}_{0}} \mathrm{~V}_{\mathrm{in}}$

The DC-link voltage $\left(\mathrm{V}_{\mathrm{DC}}\right)$ and boost factor $(\mathrm{B})$ also can be derived as:

$\mathrm{V}_{\mathrm{DC}}=\frac{1}{1-2 \mathrm{D}_{0}} \mathrm{~V}_{\mathrm{in}}=\mathrm{BV}_{\mathrm{in}}$

The phase voltage can be expressed by DC-link voltage $\left(\mathrm{V}_{\mathrm{DC}}\right)$ :

$\mathrm{V}_{\text {Phase }}=\frac{1}{2} \mathrm{~m}_{\mathrm{a}} * \mathrm{~V}_{\mathrm{DC}} * \sin (\mathrm{wt}+\alpha)$

where $\mathrm{m}_{\mathrm{a}}$ is the modulation index and $\alpha$ is the phase shift.

The relationship of peak ac voltage (phase to neutral) and input voltage can be derived from (3) and (4):

$\widehat{V}_{\text {Phase }}=\frac{1}{2} \mathrm{~m}_{\mathrm{a}} * \mathrm{BV}_{\text {in }}=\frac{1}{2} \mathrm{~m}_{\mathrm{a}} * \frac{\mathrm{V}_{\text {in }}}{1-2 \mathrm{D}}=\mathrm{GV}_{\text {in }}$

where $\mathrm{G}$ is the voltage gain from input voltage to output phase voltage.

\section{a. Constant boost with third harmonic injection}

The use of constant boost control with conventional dc power sources has been investigated for a standalone load and a grid-connected system [14]. For constant power, this control method can achieve maximum voltage gain of the qZSI and keep shoot-through duty ratio constant, unlike the MBC in which the shoot-through duty ratio is changing throughout the fundamental cycle following the envelope of the reference signals. This makes CBC with $3^{\text {rd }}$ harmonic injection suitable for PV grid-connected systems, as the only source of variation in shoot-through duty ratio will be the MPPT control loop. With PV grid-connected systems, it is important to reach a required voltage gain with a lower shoot-through duty ratio and a higher modulation index. As such, the voltage stress on inverter switches will be reduced. More importantly, there are no low-frequency ripples on the inductors current in the impedance network due to the constant shoot-through intervals.

The third harmonics are injected into three sinusoidal reference signals to reduce their peak value while increasing the shoot-through allowable region [11]. These third harmonics require three times the frequency and 1/6 magnitude of fundamental components. Fig. 2 shows the sketch map of maximum constant boost control. With PV grid-connected systems, the phase of the third harmonic is varying with solar irradiance (power level). The controller design section below is showing how the third harmonic is kept in phase with the modulating signals which reduces the total harmonic distortion of the grid injected current.

The relationship between shoot-through duty cycle $\left(D_{0}\right)$ and modulation index $\left(m_{a}\right)$ is $\mathrm{D}_{0}=1-\frac{\sqrt{3}}{2} \mathrm{~m}_{\mathrm{a}}$

The voltage gain $(\mathrm{G})$ also can be derived as:

$\mathrm{G}=\mathrm{MB}=\frac{\mathrm{M}}{\sqrt{3} \mathrm{M}-1}$ 


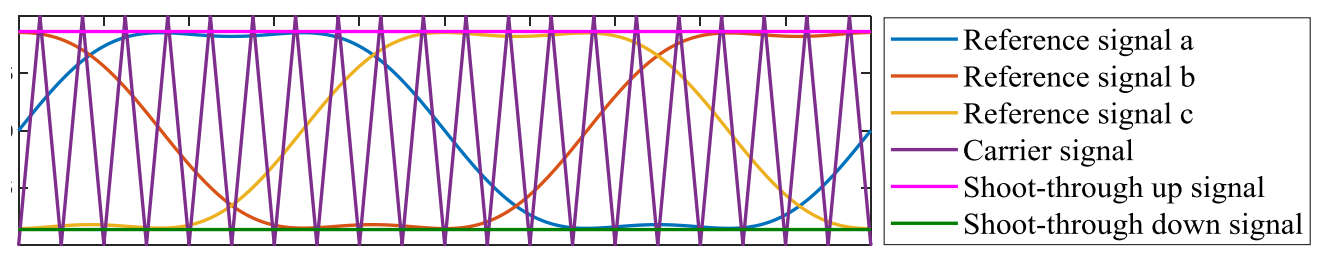

Fig. 2: Sketch map of constant boost control with third harmonic injection.

\section{b. Comparison with $\mathrm{SBC}$ and $\mathrm{MBC}$}

Fig. 3(a) compares the voltage gain $(\mathrm{G})$ of three PWM methods for qZSI versus modulation index $\left(\mathrm{m}_{\mathrm{a}}\right)$. As shown, for the same modulation index, maximum boost control obtains the highest voltage gain, while the constant boost control with third harmonic injection can obtain higher voltage gain than that of simple boost control. Fig. 3(b) indicates the normalized voltage stress on inverter switches versus voltage gain $G$ in three modified PWM techniques. With the same voltage gain $G$, the maximum boost control requires lower voltage stress on switches than that of the other two control methods. However, for PV systems, the variable shoot-through duty ratio with the maximum boost control cannot track the envelope of the reference signals, as it is normally controlled by the MPPT algorithm to maximize the energy utilization of the PV array. In this case, the MBC cannot be achieved unless MPPT is disabled which is not appropriate for PV systems. Moreover, MBC requires an increased size of inductors and capacitor to reduce low-frequency ripple in the inductor current and capacitor voltage. On the other hand, for both the SBC and CBC with third harmonic injection, the shoot-through duty ratio can only be controlled by the MPPT algorithm, which makes them suitable for PV systems. As clearly shown in Fig. 3, the proposed CBC with third harmonic injection offers higher voltage gain and lower voltage stress compared to the SBC. Due to the third harmonic injection, the range of modulation index $\mathrm{M}$ is increased to $2 / \sqrt{3}$.

\section{Proposed control strategy}

The main purposes of controller design in a grid-connected system are to deliver maximum power from PV arrays with a desired power factor and a low THD. Fig. 4 shows the proposed two-stage control method for the qZSI in the PV grid-connected system, which consists of DC-side control and $\mathrm{AC}$-side control. The capacitor voltage $\mathrm{V}_{\mathrm{C} 1}$ should be regulated to a constant value in order to decouple the DC-side and AC-side control. For the DC side, the reference voltage for the PV generator is identified by the perturb and observe (P\&O) MPPT algorithm. A PI controller is then used to regulate the shoot-through duty ratio.


(a)

(b)

Fig. 3: Three PWM techniques comparison. (a) Voltage gain $(G)$ versus modulation index $\left(\mathrm{m}_{\mathrm{a}}\right)$. (b) Normalized Voltage Stress on switches versus Voltage gain (G). 




Fig. 4: Overall diagram of the two-stage control method for QZSI in PV grid-connected system.

The AC-side control system is accomplished in the synchronous d-q reference frame. The capacitor voltage $\mathrm{V}_{\mathrm{C} 1}$ is regulated by a PI controller to provide the $\mathrm{d}$-axis current reference $\mathrm{I}_{\mathrm{d}-\text { ref }}$. The $\mathrm{q}$-axis current reference is considered zero as the unity power factor is desired. The output signals of the current controller are sent to the CBC control unit to produce the required PWM signals for inverter switches. The three reference sinusoidal signals can be produced from the phase angle wt and the $\mathrm{d}$ and $\mathrm{q}$ components of the reference modulation index $\left(\mathrm{m}_{\mathrm{d}}, \mathrm{m}_{\mathrm{q}}\right)$ as follows:

$\mathrm{V}_{\mathrm{a}}=\mathrm{m}_{\mathrm{d}} * \sin (\mathrm{wt})+\mathrm{m}_{\mathrm{q}} * \cos (\mathrm{wt})$

$\mathrm{V}_{\mathrm{b}}=\mathrm{m}_{\mathrm{d}} * \sin (\mathrm{wt}-2 \pi / 3)+\mathrm{m}_{\mathrm{q}} * \cos (\mathrm{wt}-2 \pi / 3)$

$\mathrm{V}_{\mathrm{c}}=\mathrm{m}_{\mathrm{d}} * \sin (\mathrm{wt}+2 \pi / 3)+\mathrm{m}_{\mathrm{q}} * \cos (\mathrm{wt}+2 \pi / 3)$

Normally, in third harmonic injection, the phase of the third harmonic is three times that of the fundamental. If the above equations are used in calculating the third harmonic, this means the phase shift between the modulating signals and the grid voltage $(\alpha)$ will be neglected in third harmonic calculation. For constant power application, that phase shift can be calculated and added as a constant to the phase of the third harmonic to keep it synchronized with the modulating signal. With PV grid connected applications, the phase shift between the modulating signals and the grid voltages is changing with irradiance variations. In this case, if a constant phase shift is considered in the third harmonic injection, the injected signals may lose synchronization with the fundamental resulting in a large THD.

In the proposed control strategy, instead of using the standard d-q/ABC transformation, the fundamental three phase reference signals are directly calculated from the modulation index $\mathrm{m}_{\mathrm{d}}$ and $\mathrm{m}_{\mathrm{q}}$ as follows:

$\mathrm{m}_{\mathrm{a}}=\sqrt{\mathrm{m}_{\mathrm{d}}^{2}+\mathrm{m}_{\mathrm{q}}^{2}}$

$\alpha=\operatorname{Tan}^{-1}\left(\mathrm{~m}_{\mathrm{q}} / \mathrm{m}_{\mathrm{d}}\right)$

where $m_{a}$ is the amplitude of the reference signal (the modulation index).

Based on the above equations, three reference signals can be transferred from (8-10):

$\mathrm{V}_{\mathrm{a}}=\mathrm{m}_{\mathrm{a}} * \sin (\mathrm{wt}+\alpha)$

$\mathrm{V}_{\mathrm{b}}=\mathrm{m}_{\mathrm{a}} * \sin (\mathrm{wt}+\alpha-2 \pi / 3)$

$\mathrm{V}_{\mathrm{c}}=\mathrm{m}_{\mathrm{a}} * \sin (\mathrm{wt}+\alpha+2 \pi / 3)$

Although equations 13-15 produce the same fundamental reference signals calculated by equations 810 , the use of them in calculating the third harmonic will keep that third harmonic synchronized with 
the fundamental, as the phase shift angle is now considered in calculating the phase angle for the injected third harmonic as follows:

$\mathrm{V}_{3 \mathrm{rd}}=\frac{1}{6} \mathrm{~m}_{\mathrm{a}} * \sin [3(\mathrm{wt}+\alpha)]$

It worth confirming that the amplitude of the third harmonic is set at $1 / 6$ of that of the amplitude of the reference similar to the standard third harmonic injection methods. The modulating signals for the SPWM is then calculated by adding the third harmonic calculated by (16) to the fundamental reference signals calculated by (13)-(15).

\section{Simulation Results}

In order to evaluate the performance of the proposed control scheme, the system is simulated in MATLAB/Simulink. The specifications of the proposed system are presented in Table II. The passive components of the qZSI are calculated following the small signal modelling and stability analysis in [15]. The PI controller gains for the current controller $\left(\mathrm{K}_{\mathrm{p}_{\mathrm{g}}}\right.$ and $\left.\mathrm{K}_{\mathrm{i} \_\mathrm{g}}\right)$ are set at 0.3 and 100 , respectively. These gains are obtained initially by using Ziegler-Nichols method and then fine-tuned by using trial and error to maintain a fast response and reference tracking. The response of $\mathrm{V}_{\mathrm{C} 1}$ control loop should be faster than Vin control loop and lower than the inner current loop, therefore, $\mathrm{K}_{\mathrm{p}_{-} \mathrm{C} 1}=-$ $0.005, \mathrm{~K}_{\mathrm{i} \_\mathrm{C} 1}=-0.83, \mathrm{~K}_{\mathrm{p} \_ \text {in }}=0.004, \mathrm{~K}_{\mathrm{i} \_ \text {in }}=0.4$, respectively.

In order to avoid the overlap of shoot-through duty ratio $\left(\mathrm{D}_{0}\right)$ and modulation index $\left(\mathrm{m}_{\mathrm{a}}\right)$, the proper capacitor voltage reference can be obtained from equation [12]:

$\mathrm{V}_{\mathrm{C} 1} \geq \sqrt{3} \mathrm{~V}_{\mathrm{P}_{\text {-peak }}} \approx 1.732 \mathrm{~V}_{\mathrm{P}_{\text {-peak }}}$

The grid RMS phase voltage $\left(\mathrm{V}_{\mathrm{grid}(\mathrm{ph})}\right)$ is $240 \mathrm{~V}$, thus the capacitor voltage reference was selected as $590 \mathrm{~V}$. Without third harmonic injection, the reference voltage for $\mathrm{V}_{\mathrm{C} 1}$ should be set at two times the peak value of the phase voltage $(680 \mathrm{~V})$. Furthermore, this reference signal cannot be set too large as high DC-link voltage would increase voltage stress on inverter switches. The specifications of the proposed system are presented in Table II.

\section{Table II: Specifications of the proposed system}

\begin{tabular}{|l|l|}
\hline Module's open circuit voltage & $\mathrm{V}_{\mathrm{OC}}=64.2 \mathrm{~V}$ \\
\hline Module's short circuit current & $\mathrm{I}_{\mathrm{SC}}=5.96 \mathrm{~A}$ \\
\hline Module's voltage at the maximum power point & $\mathrm{V}_{\mathrm{MPP}}=54.7 \mathrm{~V}$ \\
\hline Module's current at the maximum power point & $\mathrm{I}_{\mathrm{MPP}}=5.58 \mathrm{~A}$ \\
\hline Selected capacitor voltage & $\mathrm{V}_{\mathrm{C} 1}=590 \mathrm{~V}$ \\
\hline Rms grid phase-to-phase voltage & $\mathrm{V}_{\mathrm{grid}(\mathrm{ph}) \mathrm{rms}}=240 \mathrm{~V}$ \\
\hline Grid frequency/ Switching frequency & $\mathrm{f}_{\mathrm{grid}}=50 \mathrm{~Hz} / \mathrm{f}_{\mathrm{switching}}=10 \mathrm{kHz}$ \\
\hline Inductors in quasi-Z-source network & $\mathrm{L}_{1}, \mathrm{~L}_{2}=1000 \mu \mathrm{H}, \mathrm{r}_{\mathrm{L}}=0.01 \Omega$ \\
\hline Capacitors in quasi-Z-source network & $\mathrm{C}_{1}, \mathrm{C}_{2}=1000 \mu \mathrm{F}, \mathrm{r}_{\mathrm{C}}=0.1 \Omega$ \\
\hline Three-phase filter inductors & $\mathrm{L}_{\mathrm{f}}=5 \mathrm{mH}, \mathrm{r}_{\mathrm{f}}=0.05 \Omega$ \\
\hline Three-phase filter capacitors & $\mathrm{C}_{\mathrm{f}}=10 \mu \mathrm{F}$ \\
\hline Line impedance & $\mathrm{L}_{\mathrm{g}}=100 \mu \mathrm{H}, \mathrm{R}_{\mathrm{g}}=0.03 \Omega$ \\
\hline
\end{tabular}

Fig. 5 shows the voltage, current and power waveforms of the PV array under different irradiance levels. The PV array used, in this case, includes 5 parallel branches of 9 series connected modules. The specifications of the used PV module are shown in Table II. The solar irradiation is decreased from $1000 \mathrm{~W} / \mathrm{m}^{2}$ to $600 \mathrm{~W} / \mathrm{m}^{2}$ at $0.25 \mathrm{~s}$ and then increased to $800 \mathrm{~W} / \mathrm{m}^{2}$ at $0.4 \mathrm{~s}$. As shown, the PV voltage, current and power are following the irradiance change with fast transient response and small steady-state error.

Fig. 6 (a) indicates the two shoot-through signals from DC-side and three sinusoidal signals with third harmonic injection. Fig. 6 (b) shows the capacitor voltage is kept constant by AC-side control, with insignificant overshoots corresponding to irradiance step changes. Fig. 6 (c) indicates the maximum voltage stress on switches of $720 \mathrm{~V}$, which is much lower than that in simple boost (SB) control (850V- 
900V, c.f. Fig. 8). This allows the use of lower-rated power devices which reduces the conduction losses and also the converter cost.

Fig. 7 (a) and (b) show the grid phase voltage ( $\left.V_{\text {grid_phase }}\right)$, the grid current ( $\left.I_{\text {grid_phase }}\right)$ and the power injected to the grid. As shown, the injected current and power are varying based on solar irradiance variations. The unity power factor is maintained by setting the q-axis current reference to zero, making the grid current and voltage in phase. The THD of the grid current depends on the irradiance level and is higher at low irradiance levels as illustrated in Table III. It worth mentioning that the PI controller gains are optimized at the rated power corresponding to an irradiance of $1000 \mathrm{~W} / \mathrm{m}^{2}$ and consequently are not optimum for lower irradiance levels. For better operation at the different irradiance level, the controller parameters need to be varying.
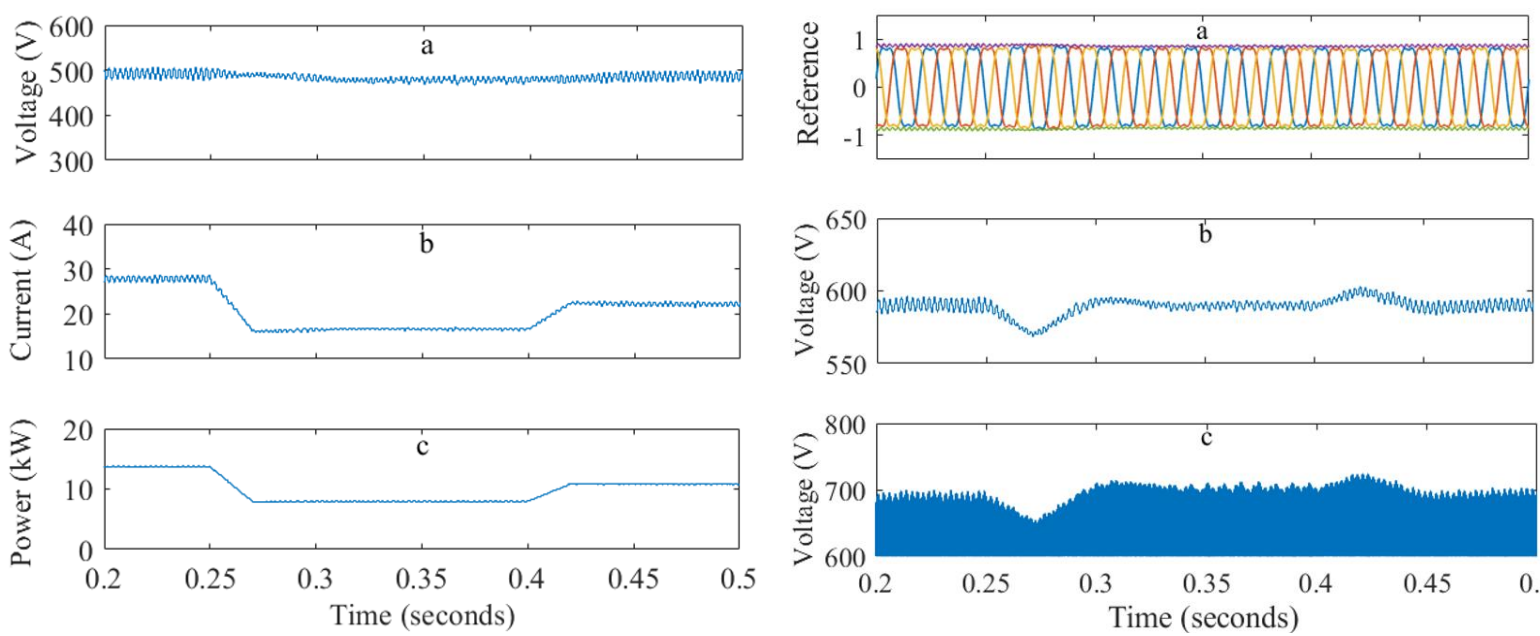

Fig. 5: Characteristics of PV arrays. (a) PV voltage. (b) PV current. (c) PV power.



Fig. 6: Operation of the control system. (a)

Reference signals. (b) Capacitor voltage. (c) Voltage stress on switches.

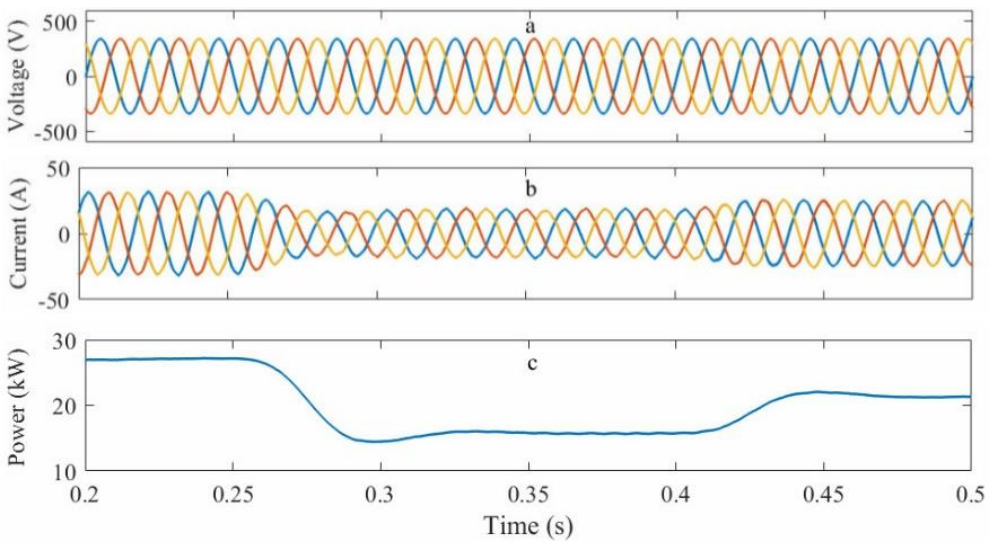

Fig. 7: Performance of the control system. (a) Grid phase voltage. (b) Grid phase current. (c) Injected power to grid.

Table III: THD contents of the control scheme under different irradiance levels.

\begin{tabular}{|l|l|l|l|l|l|}
\hline Irradiance levels & 1000 & 800 & 600 & 400 & 250 \\
\hline THD (\%) & 2.01 & 1.97 & 2.91 & 3.71 & 7.27 \\
\hline
\end{tabular}

Fig. 8 shows the voltage stress on inverter switches (dc link voltage) with both the SBC and the proposed $\mathrm{CBC}$ with third harmonic injection for the same input and output voltages and the same PV array configuration. It is clear that the proposed control reduces the voltage stress on switches compared to the SBC (from $860 \mathrm{~V}$ to $690 \mathrm{~V}$ ). 


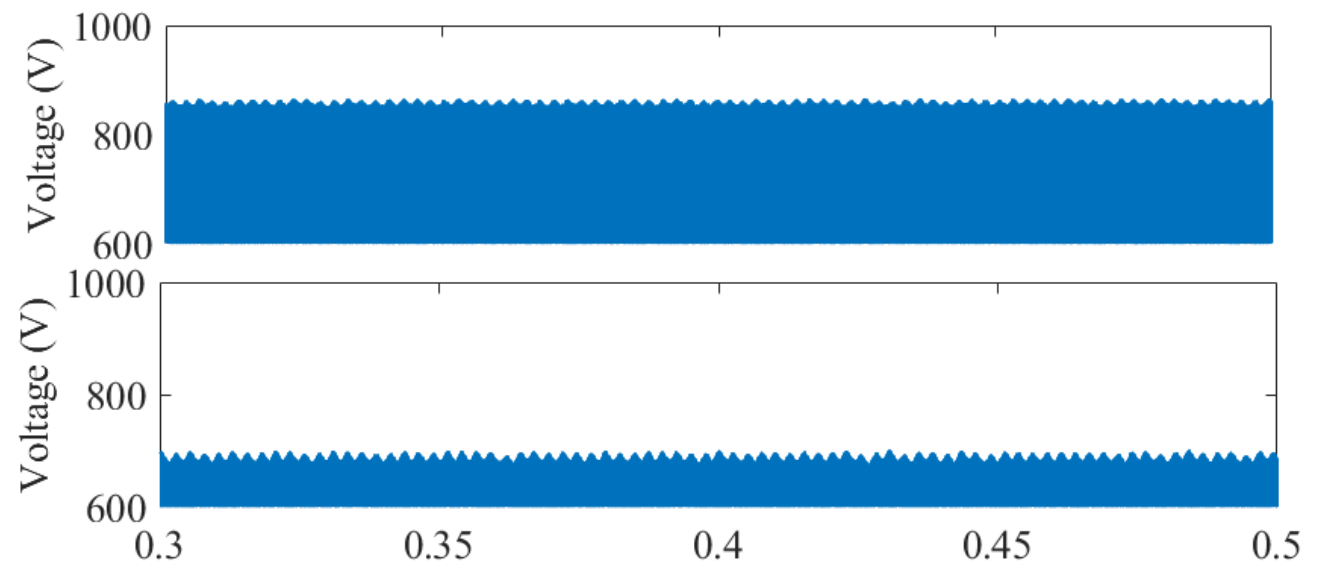

Fig. 8: Switch voltage stress with SBC (the upper plot) and proposed CBC with third harmonic injection (the lower plot).

When a lower number of series connected module is used (which is preferred for better partial shading operation), a higher voltage gain will be needed and this will result in a higher voltage stress on switches as illustrated in Fig. 3 (b), for both the SBC and proposed CBC methods. However, due to the higher voltage gain capability and lower voltage stress of the proposed method, it can be used with lower number of series connected modules with less significant increase in the voltage stress. For example, if the 30 module PV array considered in this paper is rearranged to be 10 parallel branches of 3 series-connected module, the dc link voltage will be about 1150 and 1040 with the SBC and proposed $\mathrm{CBC}$, respectively. If the PV array is reconfigured to be 15 parallel branches of 2 series connected module, the SBC cannot be used because a shoot-through duty ratio of higher than $50 \%$ (which is impossible) will be required to provide the required voltage gain. On the other hand, the proposed $\mathrm{CBC}$ can be used with this configuration but the voltage stress on switches will be about $1100 \mathrm{~V}$.

\section{Conclusion}

This paper presented a control strategy for the quasi-Z source inverter used in PV grid-connected applications. The proposed strategy employs the constant boost control with third harmonic injection, integrated with AC and DC control, to control the qZSI. A unity power factor and maximum power delivery to the grid have been achieved. Simulation results showed that lower voltage stresses on components and higher voltage gain are achieved by the proposed control method compared to the standard simple boost control.

\section{References}

[1] F. Z. Peng, “Z-source inverter,” IEEE Trans. Ind. Appl., Vol. 39, No.2, pp. 504-510, Mar./Apr. 2003.

[2] M. S. Shen, A. Joseph, J. Wang, F. Z. Peng, and D. J. Adams, "Comparison of traditional inverters and z source inverter for fuel cell vehicles,” IEEE Trans. Power Electron., Vol.22, No.4, pp.1453- 1463, Jul. 2007.

[3] J. Anderson and F. Z. Peng, "Four quasi-Z-Source inverters," in Proc, IEEE PESC'08, pp.2743-2749, Jun. 2008.

[4] J. Anderson, and F.Z. Peng, “A Class of Quasi-Z-Source Inverters,” in Proc, IEEE IAS '08. Vol. 1, No. 7, pp.5-9, Oct. 2008.

[5] M. K. Nguyen, Y. C. Lim, and G. B. Cho, "Switched-inductor quasi-Z-source inverter," IEEE Trans. Power Electron., Vol. 26, No. 11, pp. 3183-3191, Nov. 2011.

[6] D. Kai, J. Zheng, and J. Mei. "Novel switched-inductor quasi-Z-source inverter." Journal of power Electronics, Vol.14, No.1, pp. 11-21, 2014.

[7] H. F. Ahmed, H. Cha, S. H. Kim, et al. "Switched-coupled-inductor quasi-Z-source inverter." IEEE Transactions on Power Electronics, Vol. 31, No. 2, pp. 1241-1254, 2016. 
[8] Q. Wei, F. Z. Peng, and H. Cha. "Trans-Z-source inverters." IEEE transactions on power electronics Vol. 26, No.12, pp.3453-3463, 2011.

[9] S. Yang, F. Z. Peng, Q. Lei, R. Inoshita, and Z. Qian, "Current-fed quasi-Z-source inverter with voltage buck-boost and regeneration capability,” IEEE Trans. Ind. Appl., Vol. 47, No. 2, pp. 882-892, Mar./Apr. 2011 .

[10] F. Z. Peng, M. S. Shen, and Z. M. Qian, “Maximum boost control of the Z-source inverter," IEEE Trans. Power Electron., Vol. 20, No .4, pp.833-838, Jul. 2005.

[11] M. S. Shen, J. Wang, A. Joseph, F. Z. Peng, L. M. Tolbert, and D. J. Adams, "Constant boost control of the Z-source inverter to minimize current ripple and voltage stress,” IEEE Trans. Ind. Appl., Vol. 42, No. 3, pp.770-778, May/Jun. 2006.

[12] Y. Li, S. Jiang and J. G. Cintron-Rivera. "Modeling and control of quasi-Z-source inverter for distributed generation applications," IEEE Transactions on Industrial Electronics Vol. 60, No. 4, pp. 1532-1541, 2012.

[13] J. Park, H. Kim and E. Nho, “Grid-connected PV system using a quasi-Z-source inverter," Twenty-Fourth Annual IEEE Applied Power Electronics Conference and Exposition. IEEE, pp. 925-929, 2009.

[14] Khajesalehi, J., Sheshyekani, K., Hamzeh, M., et al.: "Maximum constant boost approach for controlling quasi-Z-source-based interlinking converters in hybrid AC-DC microgrids," IET Gener. Transm. Distrib., Vol. 10, No. 4, pp. 938-948, 2016.

[15] Y. Li, F. Z. Peng. "AC small signal modeling, analysis and control of quasi-Z-Source Converter," Proceedings of The 7th International Power Electronics and Motion Control Conference. Vol. 3, pp.1848-1854, 2012. 